\begin{tabular}{|l|l|}
\hline RECibido / Received & 2 de febrero de 2021 \\
\hline ACEPTADo / AcEPTED & 3 de marzo de 2021 \\
\hline
\end{tabular}

\title{
La casa de las miradas
}

\author{
Autor / Author \\ MENCARELl, Daniele
}

Editorial / Publishing company

ENCUENTRO, Madrid 2020

oscientas setenta y seis páginas sirven para que Daniele Mencarelli comparta con nosotros un año crucial en su vida, tan determinante que consiguió sacarlo del pozo profundo en que se encontraba sumergido y al que había arrastrado a su familia. En 1999 Mencarelli tenía 25 años, un joven con toda una vida por delante y, sin embargo, se encontraba al borde del abismo. El autor narra cómo por su fragilidad desarrolla una dependencia del alcohol que le había llevado a desear incluso la muerte: «Quería acabar con todo, no veía otra salida, pero pensar en el suicidio y ponerlo en práctica son dos cosas bien distintas» (p. 31). Su amigo Davide le ayudó a conseguir un trabajo en el hospital pediátrico, el Bambino Gesù. Allí, rodeado del sufrimiento de aquellos niños, acompañado de sus nuevos colegas del servicio de limpieza del hospital y con la espera silenciosa de unos padres y hermanos ante lo que la vida le acontece, Daniele es capaz de mirar de otra manera al mundo y recuperar la ilusión por seguir adelante.

Daniele describe todo lo vivido y nos descubre lo que ocurría en su mente y en su corazón. El joven vive atormentado porque no puede asumir que el amor y la belleza estén condenados a desaparecer con la muerte. No es posible que lo que ve a su alrededor deje de existir mañana. La obsesión por saber que no puede hacer nada por evitar el trágico destino del mundo lo lleva a intentar acallar la pregunta por el sentido de la vida. La huida de aquello es el alcohol, que le permite olvidar todo. Sus padres intentaron ayudarle con psicólogos y médicos, pero Daniele sabe que no está enfermo, se trata de algo tan profundo que la ciencia no puede entender lo que le sucede: «Yo no estoy enfermo, estoy más que vivo, desmesuradamente vivo, como una bestia más consciente que las demás bestias» (p. 10). Se encuentra en un mundo que no entiende el sufrimiento de su alma: «Actualmente ya no está permitido que los hombres nos hagamos preguntas, que abracemos hasta el final la insensatez sobre la que hemos construido certezas absurdas. La vida, el trabajo, el formar una familia..., en todo tienes que creer como un soldado en guerra, ignorando que una cosa de nada puede desencadenar el destino, terminar con todo. Porque todo termina, no queda nada. Esta nada 
es la que me mata, lo que me ha llevado a este presente tan vacío. Bastaría con que dejase de preguntar, de buscar, bastaría con que fingiese no sentir en todas partes la ausencia de algo, de alguien» (p. 10). A Daniele le duele el alma, le duele la vida. No es un hombre demasiado sensible, como le dicen, es un joven demasiado humano, que no está dispuesto a renunciar a la pregunta aunque esta duela cuando no se encuentra una respuesta a la que asirse. La vida duele cuando ves que todos los sentidos que se te ofrecen son tan limitados como cada uno de nosotros.

El joven había encontrado en la poesía su consuelo, pero no fue suficiente. La belleza, la verdad, el bien se dan la mano. Sin embargo, cuando el miedo y la duda se imponen, el corazón inquieto del hombre no reposa. Daniele busca pero no encuentra. Y, entonces, el vaso de vino blanco le promete el triunfo; aunque sea por una noche, el olvido se impone, el letargo triunfa, el hombre descansa hasta el nuevo día. Y, por qué no, la siguiente noche es fácil caer de nuevo en la cama acompañado por la botella. Fuera, una madre dormida sobre los tres escalones que conducen a la habitación del hijo, meciendo la ausencia de recuerdos para que él descanse. Un círculo vicioso en que el final está escrito, un día ya no será Daniele Mencarelli: será la nada.

De repente, cuando parece que no es posible escapar del drama, surge la oportunidad laboral para el joven: el servicio de limpieza de un hospital. Resulta paradójico: ante el dolor por la pregunta del sentido de la vida, le ofrecen contemplar el sufrimiento de unos niños y sus familias que se enfrentan cada día con la enfermedad y la muerte. Daniele tendrá que ver en su nuevo trabajo las vidas de niños inocentes truncadas por un trágico final. Sus padres no creen que sea una buena idea ni que sea capaz de aguantar en aquel sitio. El mismo Daniele duda pero quiere intentarlo. No puede seguir haciendo sufrir a los que más quiere: «Desde hace años la cena es una procesión de miradas y silencios. Se come para alimentar el cuerpo, pero ya no para dar vida a un rito de compartir en familia, de diálogo o de juego. Antes no era así. Después llegué yo. Pensarlo me quita la poca hambre que tengo. Solo querría echarme al suelo, besar los pies de aquellos a quienes amo y a quienes estoy haciendo sufrir. Solo querría pedir disculpas, poder volver atrás, no tener que cargar con lo que soy» (p. 20). Tal vez aquel trabajo sea el último intento de no sucumbir definitivamente.

Los comienzos en el hospital requieren un gran esfuerzo, aunque el cansancio físico puede ser una terapia para que descanse su alma atormentada. Sin embargo, Daniele no se lamenta de limpiar retretes, vómitos, todo tipo de inmundicia humana. Llora por lo que no puede limpiar con la pulidora o la manguera a presión, llora por las vidas no vividas de los niños que mueren entre aquellas paredes, llora por los que nunca salen de la habitación a respirar al campo y a acariciar una flor, llora por aquellos padres desgarrados, cadáveres vivientes que despiden los ataúdes blancos llenos de sueños jamás vividos.

Según van pasando los días, Daniele describe su sufrimiento. No bebía entre semana, pero recaía los fines de semana. Relata los altibajos, los diálogos con sus compañeros de trabajo, las promesas incumplidas a su familia, las miradas a través de los cristales de Toctoc (el niño que sin conocer su nombre llega a lo más profundo del corazón de Daniele). Pero si hay un momento frontera para el autor es el episodio que vive cuando entra a limpiar un cuarto y se encuentra con un niño de unos tres años que tiene el rostro desfigurado. El niño está con sus 
padres, Daniele es incapaz de mirar aquella cara; en ese instante entra una monja y acaricia el rostro del niño, juguetea con él, le dice lo guapo que es y lo bello de su interior. Entonces, Daniele cuenta: «He visto algo humano y al mismo tiempo de otro mundo, como un rito proveniente de una tierra muy lejana, dentro de mí no logro encontrar instrumentos para traducirlo a mi lengua. La mañana se agota detrás de esta borrachera sobria, he probado con todos los enfoques posibles, he intentado liquidar lo que he visto como el delirio de una vieja vestida de gris, luego como el fatalismo de una monja sorda y ciega al dolor que quería por todos los medios afirmar la supremacía de su Dios, incluso ante esa deformidad [...]. Sin embargo, ninguna lectura consigue colmar la distancia entre lo que he visto y mi lógica» (p. 224).

Daniele ha presenciado la experiencia del amor, un amor que va más allá del horror del rostro deformado, un amor que descubre el valor de aquel niño. El horror, el dolor, la muerte no tienen la última palabra. Todo lo terrible que pasa a nuestro lado, todo lo bello que querríamos salvar y no podemos por nuestra impotencia parece que está redimido, salvado: «No sé por qué estoy aquí, qué estoy buscando, solo tengo una certeza: lo que he visto me habla como si fuese algo nuevo. No pensaba que todavía quedaran primicias por venir» (p. 226). En ese preciso momento parece empezar a ver la luz que estaba buscando: «No hay que entender. Hay que acoger lo humano con toda la fuerza que se nos concede. Llegar a la belleza que no conoce la descomposición, al núcleo primero e inviolable. Plantar cara al horror para atravesarlo. Esta es la primacía del amor que vi en los ojos de aquella monja. Una cumbre, una altura destinada a pocos. Únicamente a quien no retrocede nunca frente a la realidad, ni cierra nunca los ojos, con una inmensa valentía en la sangre, más fuerte que cualquier miedo o egoísmo» (p. 229). Aquel instante le ha iluminado toda su vida, ya no podría huir, debía mirar la realidad a la cara.

Daniele necesita expresar aquella experiencia, pues parece que todo lo que ha sucedido desde que entró en el hospital empieza a tener sentido. Para ello, se arma de valor y visita al presidente del centro. De aquel encuentro sale con el compromiso de preparar un poemario en el que relate la esencia de lo que cada día ve por los pasillos del Bambino Gesù. Gracias a la belleza del mundo, comprende que algo inmenso le estaba siendo revelado y no lo entendía; por fin se acercaba a intuir el sentido: «Cada una de las partículas del cosmos parece estar en armonía con lo que tiene a su alrededor, nada desentona, no hay infelicidad hasta donde alcanza la vista. Dios se revela así, habla de estos momentos, en el instante en el que la respiración se detiene» (p. 238). Daniele, desde su arte, con sus poemas, se convertirá en testigo del misterio. En estas páginas el autor ha condensado su experiencia como buscador sufriente y nos hace partícipes, nos permite al resto asomarnos al misterio sagrado del diálogo del Padre con uno de sus hijos. El poder participar por medio de la lectura de La casa de las miradas de este acontecimiento es todo un privilegio.

\section{MIRÓ LÓPEZ, Susana}

Profesora doctora de Formación Humanística Universidad Francisco de Vitoria Madrid (España) 